Formatif: Jurnal Ilmiah Pendidikan MIPA

Vol. 9, No. 1, Maret 2019, pp. 11-22

p-ISSN: 2088-351X

e-ISSN: 2502-5457

DOI: http://dx.doi.org/10.30998/formatif.v9i1.2646

\title{
Uncover Student's Alternative Conception in Acid-Base Theory Using a Modified Certainty of Response Index Instrument
}

\author{
Mengungkap Konsep Alternatif Peserta Didik pada Teori Asam-Basa \\ Menggunakan Certainty Response Index Termodifikasi
}

\author{
Satya Sadhu \\ Universitas Negeri Yogyakarta
}

Received: July 11, 2018

Revised: January 24, 2019

Accepted: February 11, 2019

\begin{abstract}
Several researchers have documented alternative conception concerning chemistry subject on high school, for instance, in acid base theory. Acid base theory is a basic concept to learn other level of concept but the volume of research on student's alternative conception on acid-base has increased tremendously. It reveals that the complexity of acid base concept can tend to create student's alternative conception. Futhermore, this study addressed to reveal the student's alternative conception in acid-base theory using modified certainty of response index. The modified CRI test were administered to 148 participants who enrolled in the high school in Mataram, Indonesia. In addition, several students were interviewed in order to scrutinize their alternative conceptions. The findings revealed a number of student's alternative conceptions in acid-base theory. Student's alternative conceptions occurred because they partially understand the concept and tend to memorize it. The results have suggestion that a substantial review of teaching is needed to reduce student's alternative conception

Keywords: Student's Alternative Concept, Acid-Base Theory, Modified Certainty of Response Index
\end{abstract}

(*) Corresponding Author: $\quad$ satyasadhu @ rocketmail.com

How to Cite: Sadhu, S. (2019). Uncover student's alternative conception in acid-base theory using a modified certainty of response index instrument. Formatif: Jurnal Ilmiah Pendidikan MIPA, 9 (1): 11-22. http://dx.doi.org/10.30998/formatif.v9i1.2646

\section{PENDAHULUAN}

Memahami konsep kimia merupakan hal sangat penting bagi peserta didik. Faktanya, peserta didik sering mengalami kesulitan untuk memahami berbagai konsep kimia yang telah diterimanya dalam proses pembelajaran. Kesulitan penguasaan konsep konsep kimia terjadi karena konsep kimia yang bersifat abstrak dan membutuhkan penalaran abstrak serta sifat dari konsep kimia yang berurutan dan saling berkaitan (Kean et al. dalam Effendy, 2002; Suharto \& Monita, 2016). Alasan lainnya karena konsep kimia umumnya mengharuskan peserta didik dapat menggunakan representasi dalam tiga tingkat yang berbeda, yaitu makroskopik, mikroskopik, dan simbolik (Johnstone, 2000). Salah satu materi kimia di sekolah menengah atas (SMA) yaitu teori asam-basa. Konsep asam-basa merupakan konsep dasar untuk memahami konsep yang memiliki tingkat lebih tinggi yaitu konsep hidrolisis garam dan larutan penyangga (Artedj, et.al 2010; Sesen \& Tarhan, 2011). Di samping itu, teori asam-basa juga merupakan salah satu konsep dasar kimia yang bersifat abstrak dan melibatkan pemahaman sampai tingkat mikroskopik 
Formatif: Jurnal Ilmiah Pendidikan MIPA

Vol. 9, No. 1, Maret 2019, pp. 11-22

p-ISSN: 2088-351X

e-ISSN: 2502-5457

DOI: http://dx.doi.org/10.30998/formatif.v9i1.2646

(Hinton et al, 1999). Kompleksnya cakupan konsep asam-basa dapat menimbulkan kecenderungan bagi peserta didik untuk sulit memahaminya.

Tingkat pemahaman terhadap salah satu konsep kimia akan berpengaruh terhadap tingkat pemahaman konsep kimia lain yang akan dipelajari oleh peserta didik. Proses pembelajarannya menjadi sulit karena setiap konsep kimia harus dikuasai dengan benar sebelum mempelajari konsep kimia pada tingkat yang lebih tinggi seperti teori asam-basa. Peserta didik sering kali mengalami kesulitan, bahkan kegagalan untuk menggabungkan informasi baru yang mereka terima ke dalam struktur kognitif yang telah dibangun sebelumnya. Jika pengetahuan peserta didik tidak cukup kuat untuk memproses informasi baru tersebut, maka mereka akan menjadi bingung. Kebingungan tersebut akan menyebabkan peserta didik untuk membentuk konsep baru. Konsep baru yang dibentuk oleh peserta didik terkadang tidak sesuai dengan konsep yang dimiliki oleh para ilmuwan (konsep yang benar). Jika konsep yang dibentuk peserta didik dengan konsep yang dimiliki oleh para ilmuwan (konsep yang benar) tidak sesuai, maka konsep peserta didik disebut dengan miskonsepsi. Purtadi (2011) mengatakan bahwa dalam penelitian yang dilakukan di beberapa negara yang menunjukkan bahwa miskonsepsi yang terjadi pada peserta didik dapat bersifat resistan dan tanpa batas budaya. Konsep-konsep yang salah akan mengakibatkan peserta didik mengalami kesalahan pada konsep yang lebih tinggi atau mereka tidak memiliki kemampuan untuk menghubungkan antarkonsep. Hal tersebut mengakibatkan terjadinya rantai kesalahan konsep yang tidak terputus karena konsep awal yang dimiliki oleh perserta didik akan dijadikan sebagai dasar untuk belajar konsep selanjutnya. Di samping itu, setiap peserta didik memiliki konsepsi awal yang berbedabeda sehingga memungkinkan untuk membentuk kesalahan konsep yang berbeda pada setiap peserta didik (Juhji, 2017). Nama lain dari istilah miskonsepsi yang sering digunakan oleh para peneliti, yaitu "misconception", "children's science", "children's idea", "alternative framework", atau "alternative conception", namun istilah miskonsepsi sering kali lebih banyak mewakili semua istilah tersebut (Gunstone dalam Gilbert et al. 1992). Pada penelitian ini digunakan istilah konsep alternatif peserta didik untuk menjelaskan miskonsepsi.

Besarnya dampak negatif yang disebabkan oleh konsep alternatif atau miskonsepsi pada peserta didik membuktikan bahwa sudah seharusnya konsep alternatif tersebut perlu untuk dianalisis dan diselesaikan. Pembelajaran yang tidak memperhatikan adanya konsep alternatif menyebabkan kesulitan belajar dan jika hal tersebut terus terjadi pada peserta didik maka akan mengakibatkan prestasi belajar rendah. Salah satu upaya untuk mengetahui letak terjadinya kesalahan konsep tersebut yaitu melalui analisis terhadap pemahaman konsep peserta didik. Analisis dilakukan untuk mengetahui di mana letak kesalahan konsep peserta didik terhadap materi teori asam basa yang telah diajarkan.

Menganalisis dan mengungkap konsep alternatif peserta didik memerlukan sebuah instrumen yang tepat. Instrumen yang digunakan dalam menganalisis konsep alternatif peserta didik yaitu instrumen berbentuk two-tier. Pilihan ganda beralasan memiliki beberapa fungsi, di antaranya dapat digunakan sebagai alat untuk diagnosis terjadinya miskonsepsi pada materi pelajaran (Ododo, 2013). Item tes pada bentuk soal dikembangkan berdasarkan konsep pengetahuan peserta didik, penggambaran peta konsep peserta didik, respons dari pertanyaan peserta didik, dan respons item bebas dari peserta didik (Treagust, 1998; Treagust 2006). Penyertaan alasan pada tingkatan kedua bertujuan untuk meningkatkan keterampilan berpikir dan melihat keterampilan peserta didik dalam memberikan alasan terhadap keputusan mereka (Kwen \& Cheng, 2005; Tsui \& Treagust, 2010). 
Formatif: Jurnal Ilmiah Pendidikan MIPA

Vol. 9, No. 1, Maret 2019, pp. 11-22

p-ISSN: 2088-351X

e-ISSN: 2502-5457

DOI: http://dx.doi.org/10.30998/formatif.v9i1.2646

Dalam pengembangannya, untuk mendiagnosa konsep alternatif, maka berkembang instrumen yang berbentuk three-tier. Salah satu instrumen berbentuk threetier yaitu modified certainty of response index. CRI dikembangkan dengan menambah tingkat keyakinan atau kepastian responden dalam menjawab setiap pertanyaan yang diberikan. Oleh karena itu, penggunaan CRI termodifikasi dapat menganalisis lebih dalam adanya konsep alternatif pada teori asam-basa.

\section{METODE}

Penelitian ini merupakan penelitian deskriptif kualitatif. Menurut Sudjana (2005) penelitian deskriptif bertujuan untuk mendeskripsikan suatu peristiwa, gejala, atau kejadian yang terjadi pada masa sekarang. Dalam hal ini peristiwa yang diteliti adalah konsep alternatif atau miskonsepsi yang dialami oleh peserta didik pada teori asam-basa. Pada penelitian ini, peneliti tidak memberikan perlakuan terhadap subjek penelitian, baik model atau metode pengajaran yang dilakukan. Hal tersebut bertujuan untuk mengetahui hasil murni dari suatu peristiwa yang ingin diteliti. Triangulasi sumber data dilakukan dengan menggunakan tiga metode, yaitu menggunakan instrumen CRI termodifikasi, angket pembelajaran, observasi, dan wawancara terhadap peserta didik. Hal tersebut dilakukan untuk memperoleh hasil yang valid yang saling mendukung antara data yang diperoleh.

Subjek penelitian ini terdiri dari 148 peserta didik pada salah satu sekolah menengah atas di Kota Mataram. Pemilihan subjek penelitian dilakukan dengan teknik purposive sampling, yaitu suatu metode pengambilan sampel penelitian di mana peneliti dapat menentukan subjek penelitian yang dianggap memenuhi kriteria terkait masalah yang akan diteliti (Oppong, 2013). Pemilihan kelas didasarkan pada nilai rata-rata ulangan tengah semester ganjil. Selanjutnya dipilih empat kelas dengan ketentuan dua kelas bernilai rata-rata tinggi dijadikan sebagai kelas kognitif tinggi yang memiliki nilai rata-rata homogen dan dua kelas bernilai rata-rata rendah dijadikan kelas kognitif rendah yang memiliki nilai rata-rata homogen.

Certainty of response index (CRI) termodifikasi merupakan instrumen yang digunakan untuk memperoleh data dari peserta didik. Item dalam instrumen CRI termodifikasi ini merupakan penjabaran dari indikator-indikator yang kemudian dibuat dalam bentuk pertanyaan. Prosedur penyusunan item pada instrumen dari metode CRI termodifikasi oleh Hakim (2012). Instrumen CRI dengan modifikasi adalah tipe item pilihan ganda terdiri dari tiga tingkat yaitu pada tingkat pertama tipe item pilihan ganda dari sebuah pertanyaan, tingkat kedua alasan terkait dengan jawaban pada tingkat pertama, dan tingkat ketiga merupakan tingkat kepastian jawaban. Prosedur cara menjawab pada instrumen ini yaitu peserta didik memilih pilihan jawaban yang benar pada tingkat pertama, kemudian memberikan alasan pada tingkat kedua, dan memberikan tanda tingkat kepastian jawaban pada tingkat ketiga. Contoh dari item pada instrumen CRI termodifikasi disajikan pada Gambar 1. 


\section{Formatif: Jurnal Ilmiah Pendidikan MIPA}

Vol. 9, No. 1, Maret 2019, pp. 11-22

p-ISSN: 2088-351X

e-ISSN: 2502-5457

DOI: http://dx.doi.org/10.30998/formatif.v9i1.2646

34. Perhatikan reaksi asam-basa konjugasi menurut Bronsted-Lowry berikut!

(1) $\mathrm{H}_{2} \mathrm{PO}_{4}^{-}(a q)+\mathrm{NH}_{3}(a q) \rightarrow \mathrm{HPO}_{4}{ }^{2-}(a q)+\mathrm{NH}_{4}{ }^{+}(a q)$

(2) $\mathrm{HCN}(a q)+\mathrm{H}_{2} \mathrm{O}(a q) \rightarrow \mathrm{CN}^{-}(a q)+\mathrm{H}_{3} \mathrm{O}^{+}(a q)$

Spesi yang merupakan pasangan asam basa konjugasinya adalah ...
A. $\mathrm{NH}_{3}$ dan $\mathrm{HPO}_{4}{ }^{2-}$
C. $\mathrm{HCN}$ dan $\mathrm{H}_{3} \mathrm{O}^{+}$
B. $\mathrm{H}_{2} \mathrm{O}$ dan $\mathrm{CN}^{-}$
D. $\mathrm{H}_{2} \mathrm{PO}_{4}^{-}$dan $\mathrm{HPO}_{4}{ }^{2-}$

Alasan

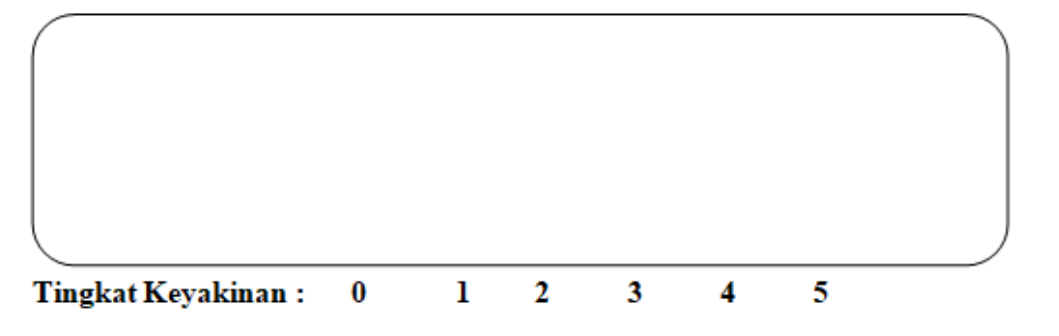

Gambar 1. Contoh item pada instrumen certainty of response index (CRI)

Terdapat sebanyak 37 butir item yang digunakan dalam instrumen CRI termodifikasi. Instrumen tersebut telah melewati uji kualitas instrumen, yaitu validitas isi, validitas butir dan reliabilitas instrumen. Validitas isi dari instrumen CRI termodifikasi melalui expert judgment diperoleh validitas isi pada aspek materi, konstruk, bahasa, dan tampilan secara berurutan, yaitu 0,$85 ; 0,933 ; 0,972$; dan 1 . Hal tersebut mengindikasikan bahwa validitas isi instrumen pada empat aspek sangat baik.Nilai validitas butir soal pada instrumen CRI berkisar antara rentang 0,622-0,213. Nilai reliabilitas instrumen CRI termodifikasi yaitu sebesar 0,851 (sangat tinggi). Hal tersebut mengindikasikan bahwa kemampuan instrumen CRI termodifikasi untuk mengumpulkan data secara tetap atau konsisten sangat tinggi.

Angket pembelajaran juga digunakan untuk menganalisis sumber adanya konsep alternatif peserta didik. Angket pembelajaran peserta didik berupa kuisioner pendapat mengenai pembelajaran, penguasaan konsep guru, dan konteks buku pelajaran kimia pada materi teori asam-basa. Pada wawancara tidak digunakannya instrumen yang baku. Wawancara yang dilakukan bersifat diagnosis dimana pertanyaannya bersumber dari jawaban siswa pada instrumen CRI yang digali lebih dalam untuk mengetahui konsep alternatif yang ada.

Analisis data yang digunakan adalah analisis data secara deskripif kualitatif. Data yang diperoleh dari instrumen CRI dianalisis sesuai dengan analisis CRI dengan bantuan Microsoft Excel. Hasil akhir analisis yang berupa angka dibuatkan presentase dan disajikan dalam bentuk tabel. Nilai persentase dideskripsikan secara naratif. Konsep alternatif peserta didik pada teori asam-basa diperoleh dari analisis jawaban peserta didik pada tingkat dua (alasan). Hasil observasi dalam proses pembelajaran dan observasi terhadap sumber-sumber belajar peserta didik, serta hasil wawancara dengan peserta didik yang dikategorikan memiliki konsep alternatif dianalisis secara deskriptif untuk mengungkap kesalahan konsep yang terjadi pada peserta didik. 
Formatif: Jurnal Ilmiah Pendidikan MIPA

Vol. 9, No. 1, Maret 2019, pp. 11-22

p-ISSN: 2088-351X

e-ISSN: 2502-5457

DOI: http://dx.doi.org/10.30998/formatif.v9i1.2646

\section{HASIL DAN PEMBAHASAN}

\section{Hasil}

Berdasarkan hasil data tes objektif menggunakan instrumen certainty of response index termodifikasi menunjukkan bahwa masih banyak peserta didik yang mengalami miskonsepsi. Berikut ditampilan tabel data persentasi miskonsepsi pada teori asam-basa.

Tabel 1. Hasil Persentase Miskonsepsi pada Teori Asam-Basa

\begin{tabular}{ccc}
\hline No & Subteori Asam-Basa & Persentase Miskonsepsi (\%) \\
\hline 1 & Teori Asam-Basa Arrhenius & 35.06 \\
2 & Teori Asam-Basa Bronsted-Lowry & 33.80 \\
3 & Teori Asam-Basa Lewis & 33.33 \\
\hline
\end{tabular}

\section{Pembahasan}

Peserta didik yang salah konsep dalam menjawab soal tetapi memberikan tingkat keyakinan yang tinggi terhadap jawaban maka dapat dikategorikan dalam konsep alternatif atau miskonsepsi. Tingkat keyakinan jawaban peserta didik pada instrumen certainty of response index membantu dalam membedakan mana peserta didik yang tidak paham konsep dan miskonsepsi berdasarkan tingkat keyakinan yang mereka pilih terhadap jawaban yang telah dijawab. Tingkat kejujuran peserta didik dalam memberikan tingkatan kepercayaan ini merupakan faktor penentu. Besarnya miskonsepsi pada peserta didik dapat juga dikarenakan peserta didik tidak jujur dalam memilih skala keyakinan pada three tier terhadap jawaban mereka, sehingga peserta didik yang sebenarnya tidak paham konsep menjadi kategori miskonsepsi. Miskonsepsi dapat berasal dari beberapa sumber misalnya dari guru yang menyampaikan suatu konsep yang keliru, dari peserta didik sendiri, serta dapat juga dari metode mengajar yang kurang tepat (Winny et al. 2008).

Cukup tingginya persentase miskonsepsi yang terjadi pada peserta didik, bersumber dari peserta didik itu sendiri. Sumber lain yang dapat menyebabkan adanya konsep alternatif peserta didik yaitu guru, buku, konteks, dan cara mengajar. Berdasarkan kuesioner pendapat peserta didik mengenai pembelajaran dan penguasaan konsep guru serta konteks buku pelajaran kimia pada materi teori asam-basa. Diperoleh penguasan konsep guru, pengajaran, komunikasi dan manajemen kelas yang dilakukan guru berkisar antara $77-98 \%$. Serta untuk kelengkapan isi materi, tingkat kesulitan penulisan dan bahasa dalam buku berkisar antara 56-71\%. Faktor guru, cara mengajar dan buku tidak terlalu menjadi sumber miskonsepsi peserta didik.

Mempertimbangkan kekurangan dari CRI yaitu kejujuran peserta didik dalam memberikan index keyakinan, maka pada penelitian ini dianalisis lebih dalam kembali jawaban peserta didik untuk mengetahui apakah dikategorikan ke dalam konsep alternatif peserta didik atau tidak paham konsep. Beberapa jawaban peserta didik yang dianggap sebagai konsep alternatif peserta didik akan di-coding dan selanjutnya jawaban tersebut akan diselediki lebih lanjut untuk mengetahui alasan di balik terdapatnya konsep alternatif peserta didik.

Berdasarkan pengelompokkan tingkat pemahaman peserta didik melalui tes objektif menggunakan certainty of response index (CRI), maka dapat diketahui peserta didik yang mengalami miskonsepsi. Peneliti melakukan tahap wawancara diagnosis kepada peserta didik yang teridentifikasi memiliki konsep alternatif untuk mengetahui lebih dalam mengenai konsep yang dimiliki. 


\section{Formatif: Jurnal Ilmiah Pendidikan MIPA}

Vol. 9, No. 1, Maret 2019, pp. 11-22

p-ISSN: 2088-351X

e-ISSN: 2502-5457

DOI: http://dx.doi.org/10.30998/formatif.v9i1.2646

\section{Konsep Alternatif Peserta Didik pada Teori Asam-Basa Arrhenius}

Sebanyak tujuh butir soal telah digunakan untuk menelusuri konsep alternatif peserta didik mengenai subkonsep teori asam-basa Arrhenius. Tujuh soal tersebut memiliki indikator-indikator yaitu menentukan reaksi ionisasi, menentukan sifat larutan, menganalisis senyawa yang menghasilkan ion $\mathrm{H}^{+}$dan $\mathrm{OH}^{-}$, serta memilih larutan asam.

Konsep alternatif yang ditemukan, yaitu kesalahan konsep peserta didik dalam menuliskan persamaan reaksi ionisasi. Berdasarkan hasil wawancara yang telah dilakukan, konsep alternatif yang terjadi yaitu peserta didik memiliki pandangan bahwa reaksi ionisasi sama seperti reaksi penguraian, yaitu menguraikan senyawa menjadi unsur-unsurnya. Peserta didik berasumsi bahwa reaksi ionisasi $\mathrm{NaOH}$ akan menghasilkan $\mathrm{Na}^{+}$, O dan $\mathrm{H}^{+}$. Asumsi tersebut diperoleh perserta didik dari pembelarajan pada materi sebelumnya, yaitu reaksi penguraian dalam materi termokimia. Konsep alternatif ini menyebabkan peserta didik mengalami kesalahan dalam menentukan reaksi ionisasi dari senyawa $\mathrm{NaOH}$.

Berdasarkan konsep yang benar, reaksi ionisasi berbeda dengan reaksi penguraian. Reaksi ionisasi adalah proses fisik mengubah atom atau molekul menjadi ion dengan menambahkan atau mengurangi partikel bermuatan seperti elektron atau lainnya, sedangkan reaksi penguraian adalah reaksi dari sebuah senyawa yang diuraikan menjadi unsur-unsurnya. Pada teori asam-basa Arrhenius reaksi ionisasi senyawa asam atau basa yaitu reaksi yang melepaskan senyawa dalam bentuk ion, asam akan melepaskan ion $\mathrm{H}^{+}$ atau ion $\mathrm{H}_{3} \mathrm{O}^{+}$dan basa akan melepaskan ion $\mathrm{OH}^{-}$. Penyebab alternaif konsep tersebut karena peserta didik hanya memahami konsep secara parsial, tanpa mendalaminya kembali, sehingga mereka tertukar dalam memilih jawaban. Peserta didik berusaha menghubungkan konsep tersebut dengan pola pikirannya.

Konsep alternatif peserta didik terjadi juga pada indikator menentukan senyawa yang bertindak sebagai basa. Berdasarkan hasil wawancara yang telah dilakukan, diketahui konsep alternatif yang terjadi, yaitu peserta didik memiliki pandangan bahwa senyawa yang memiliki -OH di belakang suatu rumus senyawa, pasti akan melepaskan ion $\mathrm{OH}^{-}$. Seperti contoh senyawa $\mathrm{CH}_{3} \mathrm{COOH}$ yang memiliki -OH di belakang rumus senyawanya, reaksi ionisasinya akan melepaskan ion $\mathrm{OH}^{-}$, sehingga senyawa tersebut dapat digolongkan sebagai senyawa basa. Menurut pandangan peserta didik dengan adanya $-\mathrm{OH}$ di belakang suatu rumus senyawa menandakan senyawa tersebut merupakan basa Arrhenius.

Berdasarkan konsep yang benar, adanya -OH di belakang belum tentu menandakan bahwa senyawa tersebut merupakan senyawa basa. Sebagai contoh, senyawa $\mathrm{CH}_{3} \mathrm{COOH}$ yang merupakan asam asetat, bukan merupakan senyawa basa walaupun terdapat -OH di belakang rumus senyawanya. Karena reaksi ionisasi dari senyawa $\mathrm{CH}_{3} \mathrm{COOH}$ akan melepaskan ion $\mathrm{CH}_{3} \mathrm{COO}^{-}$dan $\mathrm{H}^{+}$. Contoh lainnya, yaitu senyawa $\mathrm{C}_{6} \mathrm{H}_{5} \mathrm{COOH}$, walaupun terdapat $-\mathrm{OH}$ di belakang rumus senyawanya tetapi senyawa $\mathrm{C}_{6} \mathrm{H}_{5} \mathrm{COOH}$ merupakan asam benzoat karena reaksi ionisasi dari senyawa $\mathrm{C}_{6} \mathrm{H}_{5} \mathrm{COOH}$ akan melepaskan ion $\mathrm{C}_{6} \mathrm{H}_{5} \mathrm{COO}^{-}$dan ion $\mathrm{H}^{+}$. Contoh lain, yaitu senyawa $\mathrm{NH}_{3}$ yang merupakan senyawa basa, walaupun tidak terdapat rumus kimia - $\mathrm{OH}$ di belakang, senyawa tersebut merupakan senyawa basa karena dalam reaksi ionisasi akan melepaskan ion $\mathrm{NH}_{4}^{+}$dan $\mathrm{OH}^{-}$.

\section{Konsep Alternatif Peserta Didik pada Teori Asam-Basa Bronsted-Lowry}

Terdapat 15 butir soal yang digunakan untuk menelusuri konsep alternatif peserta didik mengenai subkonsep teori asam-basa Bronsted-Lowry. Soal-soal tersebut memiliki 


\section{Formatif: Jurnal Ilmiah Pendidikan MIPA}

Vol. 9, No. 1, Maret 2019, pp. 11-22

p-ISSN: 2088-351X

e-ISSN: 2502-5457

DOI: http://dx.doi.org/10.30998/formatif.v9i1.2646

indikator-indikator soal yaitu menjelaskan definisi basa, menentukan spesi yang bertindak sebagai asam dan basa, menentukan senyawa yang dapat bertindak sebagai asam dan basa, menentukan spesi senyawa ampriprotik, menganalisis spesi yang berperan sebagai asam dan basa, menentukan sifat larutan suatu senyawa, menganalisis spesi asam/basa konjugasi, menganalisis ciri asam/basa konjugasi, serta menganalisis pasangan asam-basa konjugasi.

Konsep alternatif peserta didik terjadi pada indikator menentukan spesi yang bertindak sebagai asam. Berdasarkan hasil wawancara, diketahui konsep alternatif yang terjadi, yaitu peserta didik memiliki pandangan bahwa spesi yang memiliki proton $\mathrm{H}^{+}$ lebih banyak adalah spesi yang bertindak sebagai asam Bronsted-Lowry. Berdasarkan reaksi yang diberikan pada butir soal nomor 8 yang disajikan pada Gambar 2.

8. $\mathrm{HNO}_{3}(a q)+\mathrm{NH}_{3}(a q) \rightleftarrows \mathrm{NH}_{4}^{+}(a q)+\mathrm{NO}_{3}^{-}(a q)$

Berdasarkan reaksi tersebut yang bertindak sebagai asam menurut teori Bronsted-

Lowry adalah

$\begin{array}{ll}\text { A. } \mathrm{HNO}_{3} & \text { C. } \mathrm{NO}_{3}^{-} \\ \text {B. } \mathrm{NH}_{3} & \text { D. } \mathrm{NO}_{3}{ }^{-+} \text {dan } \mathrm{HNO}_{3}\end{array}$

Alasan :

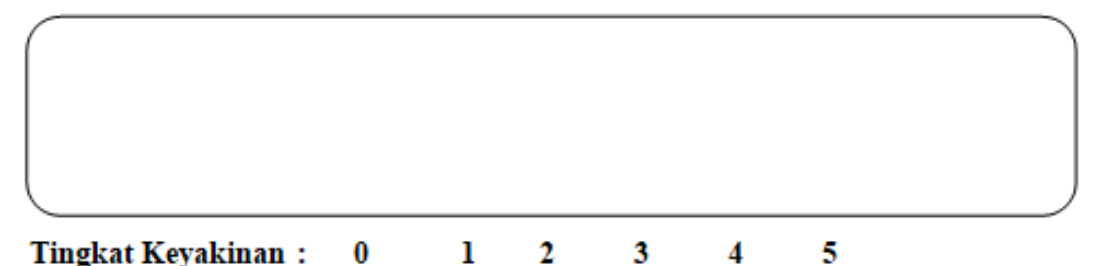

Gambar 2. Soal nomor 8 pada CRI termodifikasi

Berdasarkan pandangan peserta didik, senyawa $\mathrm{NH}_{3}$ merupakan spesi yang bertindak sebagai asam karena dibandingkan dengan senyawa $\mathrm{HNO}_{3}$ dan $\mathrm{NO}_{3}{ }^{-}$, senyawa $\mathrm{NH}_{3}$ lebih banyak mengandung proton $\mathrm{H}^{+}$. Banyaknya proton yang terdapat pada senyawa $\mathrm{NH}_{3}$ menyebabkan proton dapat disumbangkan ke senyawa lain. Konsep alternatif tersebut terjadi karena peserta didik tidak memahami konsep asam-basa Bronseted-Lowry dan tidak memperhatikan reaksi yang terjadi. Berdasarkan konsep yang benar, definisi asam Bronsted-Lowry yaitu spesi yang memberikan (donor) proton. Senyawa yang memberikan proton $\left(\mathrm{H}^{+}\right)$dapat didefinisikan sebagai spesi asam BronstedLowry. Pada soal nomor 8, senyawa $\mathrm{HNO}_{3}$ merupakan senyawa bertindak sebagai asam. Hal tersebut karena reaksi dari senyawa $\mathrm{HNO}_{3}$ yang memberikan ion $\mathrm{H}^{+}$atau proton kepada $\mathrm{NH}_{3}$, sehingga terbentuk $\mathrm{NH}_{4}{ }^{+}$. Secara lebih jelas dapat dilihat pada Gambar 3. Di sisi lain, $\mathrm{NH}_{4}{ }^{+}$juga dapat bertindak sebagai asam dengan menyerahkan protonnya kepada ion $\mathrm{NO}_{3}{ }^{-}$untuk membentuk $\mathrm{NH}_{3}$. Asam Bronsted-Lowy adalah spesi yang memberikan (donor) $\mathrm{H}^{+}$proton dalam suatu reaksi transfer proton bukan dilihat dari banyaknya kandungan proton $\mathrm{H}^{+}$. 
Formatif: Jurnal Ilmiah Pendidikan MIPA

Vol. 9, No. 1, Maret 2019, pp. 11-22

p-ISSN: 2088-351X

e-ISSN: 2502-5457

DOI: http://dx.doi.org/10.30998/formatif.v9i1.2646

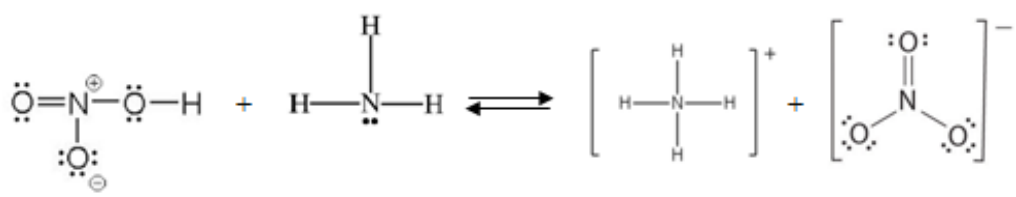

Gambar 3. Reaksi menurut asam-basa Bronsted-Lowry

Konsep alternatif peserta didik juga ditemukan pada indikator menentukan spesi yang bertindak sebagai basa. Berdasarkan hasil wawancara, peserta didik memiliki pandangan bahwa spesi yang memiliki proton $\mathrm{H}^{+}$lebih sedikit bertindak sebagai basa Bronsted-Lowry. Berdasarkan pandangan peserta didik, senyawa yang memiliki proton $\mathrm{H}^{+}$lebih sedikit didefinisikan sebagai basa menurut teori asam-basa Bronsted-Lowry, karena apa pun yang kurang dapat diberikan oleh donor. Konsep alternatif tersebut menyebabkan peserta didik salah dalam menjawab soal. Berdasarkan konsep yang benar, basa Bronsted-Lowry dapat didefinisikan sebagai spesi yang yang bertindak sebagai penerima (akseptor) proton dalam suatu reaksi transfer proton.

Konsep alternatif juga ditemukan pada indikator menentukan spesi basa konjugasi. Berdasarkan hasil wawancara, peserta didik memiliki pandangan bahwa asam konjugasi dan basa konjugasi merupakan senyawa-senyawa ion. Perserta didik berpendapat hal tersebut terjadi karena asam konjugasi dan basa konjugasi terletak pada sebelah kanan reaksi (hasil reaksi) di mana senyawa yang terletak di sebelah kanan reaksi selalu merupakan senyawa ion. Konsep alternatif lain yang ditemukan yaitu peserta didik juga berpendapat bahwa asam konjugasi merupakan senyawa yang kekurangan satu $\mathrm{H}^{+}$ dan basa konjugasi kelebihan satu $\mathrm{H}^{+}$. Konsep alternatif ini menyebabkan peserta didik salah dalam memilihi jawabannya, seperti yang disajikan pada butir soal nomor 22 pada Gambar 4.

22. Perhatikan reaksi berikut

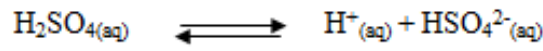

Berdasarkan reaksi di atas pernyataan yang benar berdasarkan teori asam basa

Bronsted-Lowry adalah

A. $\mathrm{H}_{2} \mathrm{SO}_{4}$ sebagai basa C. $\mathrm{HSO}_{4}{ }^{2-}$ sebagai basa konjugasi

B. $\mathrm{H}^{+}$sebagai asam

D. $\mathrm{HSO}_{4}{ }^{2-}$ sebagai asam konjugasi

Alasan :

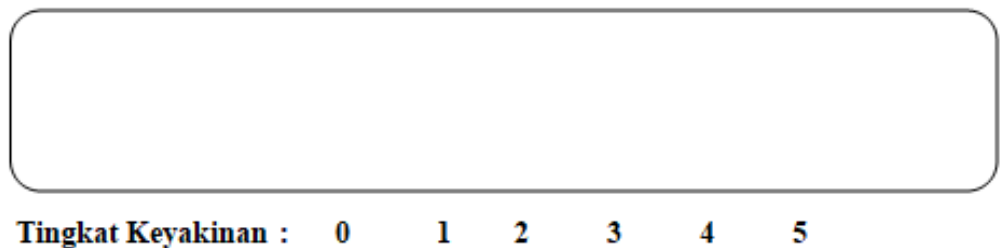

Gambar 4. Soal nomor 8 pada CRI termodifikasi

Berdasarkan konsep alternatif yang dimiliki peserta didik, dalam memilih jawaban mereka cenderung untuk memilih jawaban senyawa berupa ion. Menurut pandangan peserta didik, jawaban yang benar yaitu $\mathrm{HSO}_{4}{ }^{2-}$ sebagai asam konjugasi. Hal tersebut karena konjugasi akan selalu berbentuk senyawa ion dan jika jumlah proton pada hasil reaksi lebih sedikit daripada pereaksi, maka senyawa tersebut dikatakan sebagai asam konjugasi. 


\section{Formatif: Jurnal Ilmiah Pendidikan MIPA}

Vol. 9, No. 1, Maret 2019, pp. 11-22

p-ISSN: 2088-351X

e-ISSN: 2502-5457

DOI: http://dx.doi.org/10.30998/formatif.v9i1.2646

Berdasarkan konsep yang benar, tidak semua asam dan basa konjugasi merupakan senyawa ion. Konsep alternatif tersebut diperoleh peserta didik karena guru hanya memberikan contoh reaksi yang sama pada proses pembelajaran di dalam kelas. Oleh karena itu, peserta didik dapat menyimpulkan seperti itu dan menimbulkan adanya konsep alternatif. Konsep alternatif tersebut diperoleh peserta didik karena tidak mengetahui definisi asam-basa konjugasi secara lengkap dan benar. Peserta didik masih menggunakan definisi basa, bukan basa konjugasi. Hal yang sama juga diperoleh dari penelitian Melyindra (2013), di mana peserta didik masih sulit membedakan antara asambasa Bronsted-Lowry dengan asam konjugasi dan basa-konjugasi Bronsted-Lowry. Cukup banyaknya miskonsepsi yang terjadi pada teori asam-basa Bronsted-Lowry didukung oleh penelitian Demerouti et al. (Pabuccu, 2008) yang menunjukan bahwa peserta didik mengalami kesalahan konsep dan kesulitan dalam memahami definisi asambasa Bronsted-Lowry, jika memahami definisi salah maka mereka akan sulit dan salah konsep dalam menentukan spesi asam-basa dan asam-basa konjugasi.

\section{Konsep Alternatif Peserta Didik pada Teori Asam-Basa Lewis}

Terdapat 11 butir soal yang digunakan untuk menelusuri konsep alternatif peserta didik mengenai subkonsep teori asam-basa Lewis. Soal-soal tersebut memiliki indikatorindikator soal yaitu menjelaskan definisi asam dan basa, menjelaskan spesi asam dan basa, menentukan teori asam basa yang dapat digunakan pada suatu reaksi, menentukan spesi asam dan basa, menentukan reaksi yang sesuai dengan teori Lewis, menentukan senyawa yang dapat bertindak sebagai basa, memilih senyawa yang dapat bertindak sebagai asam dan basa, dan menganalisis spesi asam

Konsep alternatif peserta didik ditemukan pada indikator definisi asam dan basa Lewis. Berdasarkan hasil wawancara, peserta didik memiliki pandangan bahwa asam merupakan spesi yang memberi pasangan elektron dan basa Lewis merupakan spesi yang menerima pasangan elektron. Berdasarkan konsep yang benar, asam Lewis merupakan spesi yang bertindak sebagai akseptor pasangan elekton bebas dan basa Lewis merupakan spesi yang bertindak sebagai donor pasangan elektron bebas. Konsep alternatif tersebut terjadi karena peserta didik hanya menghafal definisi teori asam basa tanpa memahaminya lebih dalam. Pada saat menghafal, peserta didik cenderung sering mengalami kekeliruan dengan definisi asam-basa Bronsted-Lowry dengan asam-basa Lewis. Peserta didik cenderung menggunakan definisi asam dan basa Bronsted-Lowry pada definisi asam dan basa Lewis, yaitu asam yang memberi dan basa yang menerima karena sudah tertanam di sistem kognitif mereka. Konsep alternatif tersebut juga ditemukan oleh Meylindra (2013) yang menyatakan bahwa peserta didik masih kesulitan dalam menentukan spesi-spesi asam-basa Lewis dan menganggap dalam menentukan asam-basa Lewis sama seperti Bronsted-Lowry.

\section{Penyebab Terbentuknya Konsep Alternatif Peserta Didik}

Diketahui jenis konsep alternatif yang terjadi pada peserta didik yaitu salah paham konseptual. Salah paham konseptual merupakan salah paham yang berkembang saat peserta didik diberikan informasi ilmiah yang tidak memberi tantangan pada paradoks dari kepercayaan beku dan kepercayaan non-ilmiah di mana dapat dikatakan salah paham konseptual yaitu kesalahan penggunaan konsep.

Konsep alternatif salah paham konseptual disebabkan karena peserta didik sendiri, di mana dalam proses pembelajaran, peserta didik mencoba untuk mengolah informasi yang masuk ke dalam sistem kognitif. Jika informasi yang diterima sesuai 
Formatif: Jurnal Ilmiah Pendidikan MIPA

Vol. 9, No. 1, Maret 2019, pp. 11-22

p-ISSN: 2088-351X

e-ISSN: 2502-5457

DOI: http://dx.doi.org/10.30998/formatif.v9i1.2646

dengan struktur konsep yang ada, informasi ini akan langsung menambah jaringan pengetahuan mereka, proses ini disebut proses asimilasi. Jika informasi tidak sesuai, maka peserta didik akan melakukan penyusunan ulang struktur kognitif sehingga informasi tersebut dapat menjadi bagian dari jaringan pengetahuan mereka (Suparno dalam Sangeret al. 1997). Berdasarkan hasil penelitian, peserta didik cenderung membentuk konsep baru dari konsep yang telah ada, di mana konsep baru tersebut memudahkan untuk memahami konsep lama. Faktanya, konsep baru yang terbentuk tersebut tidak sesuai dengan konsep yang benar, sehingga peserta didik mengalami kesalahan dalam menjawab soal. Di samping itu, berdasarkan hasil observasi proses pembelajaran yang telah berlangsung, peserta didik tidak pernah mengonfirmasi atau bertanya kepada guru mengenai konsep baru atau konsep alternatif yang telah dibuat dalam proses pembelajaran.

Berdasarkan hasil analisis terhadap konsep alternatif peserta didik yang terjadi pada teori asam-basa, maka dapat disimpulkan bahwa peserta didik masih memahami konsep secara parsial atau tidak utuh dan lebih cenderung menghafal. Tingkat pencapaian konsep peserta didik hanya sampai pada tingkat identitas. Selain itu beberapa peserta didik masih salah dalam menginterpretasikan istilah dalam teori asam-basa.

Menurut Piaget (dalam Suparno, 2012) dalam teori kognitifnya menyatakan bahwa peserta didik yang masih berada dalam tahap konkret masih akan terbatas dalam mengonstruksi pengetahuannya, terlebih dalam konsep yang abstrak. Peserta didik belum dapat dengan mudah menggeneralisasi, mengabstraksi, dan berpikir sistematis logis. Pada tahap tersebut, konsepsi perserta didik tidak lengkap atau bahkan salah konsep. Sedangkan menurut Comins, penalaran peserta didik yang tidak lengkap disebabkan karena informasi atau data yang diperoleh tidak lengkap, akibatnya peserta didik menarik kesimpulan secara salah dan hal ini dapat menyebabkan timbulnya konsep alternatif baru pada peserta didik. Perolehan informasi atau data yang tidak lengkap yang diperoleh peserta didik didukung oleh hasil observasi pada proses belajar mengajar di dalam kelas. Guru menyajikan contoh konsep dengan tidak baik, seperti guru tidak mengurutkan contoh-contoh dari yang mudah hingga yang sulit. Guru tidak memilih contoh yang berbeda dari yang satu dengan yang lain serta guru tidak membandingkan juga membedakan contoh dan bukan contoh.

Hal yang terpenting dalam menyelesaikan konsep alternatif peserta didik pada teori asam-basa yaitu dengan memutus mata rantai kesalahan konsep. Pada penelitian ini, wawancara selain digunakan untuk mengetahui alasan penyebab adanya konsep alternatif juga digunakan untuk mengonfirmasi konsep alternatif yang dimiliki oleh peserta didik dengan memberikan teori dan konsep yang benar. Solusi untuk menghindari adanya konsep alternatif peserta didik ke depannya pada meteri ini. Berdasarkan pada penyebab miskonsepsi, dapat diperoleh beberapa solusi dalam melakukan strategi pembelajaran yang benar dalam teori asam-basa, yaitu pertama, guru sebaiknya mengikuti aturan dalam menyajikan konsep menurut Tenny Sonet. al. (Slavin, 2001) yaitu guru mengurutkan contoh-contoh dari yang mudah hingga yang sulit, guru memberikan contoh yang berbeda dari yang satu dengan yang lain, serta guru membandingkan dan membedakan contoh dan bukan contoh. Kedua, sebaiknya guru dapat memberikan feedback yang baik kepada peserta didik, sehingga peserta didik dapat mengutarakan atau mengonfirmasi pendapat mereka ataupun konsep-konsep baru yang mereka bentuk sendiri. Ketiga, sebaiknya guru dapat mengajarkan pembelajaran yang didasarkan pada teori konstruktivisme pada materi teori asam-basa. Keempat, untuk meningkatkan tingkat pemahaman konsep peserta didik dan menurunkan adanya konsep alternatif, guru dapat menggunakan model dan metode yang baik untuk teori asam-basa ini sehingga peserta didik dapat memahami konsep secara mikrokospik, makrokospik, dan simbolik, serta mencapai tingkat pemahaman 


\section{Formatif: Jurnal Ilmiah Pendidikan MIPA}

Vol. 9, No. 1, Maret 2019, pp. 11-22

p-ISSN: 2088-351X

e-ISSN: 2502-5457

DOI: http://dx.doi.org/10.30998/formatif.v9i1.2646

konsep tingkat formal dengan lengkap dan jelas. Kelima, ada baiknya guru untuk mencari literatur apakah materi yang diajarkan cenderung terdapat konsep alternatif atau tidak, sehingga dapat menghindari terjadinya konsep alternatif.

\section{PENUTUP}

Secara ringkas dapat disimpulkan bahwa terdapat konsep alternatif pada peserta didik terhadap teori asam-basa Arrhenius, Bronsted-Lowry, dan Lewis. Jenis konsep alternatif yang terjadi pada peserta didik yaitu salah paham konseptual. Konsep alternatif tersebut terjadi karena peserta didik masih memahami konsep secara parsial atau tidak lengkap dan lebih cenderung menghafal.

\section{DAFTAR PUSTAKA}

Artdej, R., et. al.(2010). Thai grade 11 students' alternative conceptions for acid-base chemistry. Research in Science \& Technological Education, 28(2), 167-183. https://doi.org/10.1080/02635141003748382

Effendy. (2002). Upaya untuk mengatasi kesalahan konsep dalam pengajaran dengan menggunakan strategi konflik kognitif. Media Komunikasi Kimia, 2 (6), 1-19.

Gilbert, J.K., Osborne, R.J., \& Fensham, P.J. (1982). Children's science and it's consequences for teaching. Journal of Science Education, 66 (4), 623-633. https://doi.org/10.1002/sce.3730660412

Hakim, A., Liliasari, \& Asep K. (2012). Student concept understanding of natural products chemistry in primary and secondary metabolites using the data collecting technique of modified CRI. International Online Journal of Educational Sciences, 4 (3), 544-553.

Hinton, M. E., \& Nakhleh M.B. (1999). Students' microscopic, macroscopic, and symbolic representations of chemical reactions. The Chemical Educator, 4 (4), 158-167. https://doi.org/10.1007/s00897990325a.

Juhji. (2017). Upaya mengatasi miskonsepsi siswa pada materi sistem saraf melalui penggunaan peta konsep. Formatif: Jurnal Ilmiah Pendidikan MIPA, 7(1): 33-39.

Johnstone, A.H. (2000). Teaching of chemistry-logical or psychological? Chemistry Education: Research and Practice in Europe, 1, 9-15. https://doi.org/10.1039/A9RP90001B

Kwen, B. H., \& Cheng, K. (2005). Using two-tier reflective multiple choice questions to cater to creative thinking. Proceedings ofInternational Education Research Conference National Institute of Education, Nanyang Technological University Singapore, BOO05235, 0-10.

Meylindra, I. Suhadi I., dan Oktavia S. (2012). Identifikasi Pemahaman Konsep Larutan Asam Basa melalui Gambaran Mikroskopik pada Siswa Kelas XI IPA SMA Negeri 5 Malang. Unpublished Thesis. Malang: Universitas Negeri Malang.

Monita, F. A., \& Suharto, B. (2016). Identifikasi dan analisis miskonsepsi siswa menggunakan three-tier multiple choice diagnostic instrument pada konsep kesetimbangan kimia. Quantum, Jurnal Inovasi Pendidikan Sains, 7 (1), 27-38.

Ododo, S. O. (2013). Effects of two-tier multiple choice diagnostic assessment items on student's learning outcome in basic science technology (BST). Academic Journal $\begin{array}{llll}\text { of Interdisciplinary } & \text { Studies, } & 2 & \text { (2), }\end{array}$ https://doi.org/10.5901/ajis.2013.v2n2p201 
Formatif: Jurnal Ilmiah Pendidikan MIPA

Vol. 9, No. 1, Maret 2019, pp. 11-22

p-ISSN: 2088-351X

e-ISSN: 2502-5457

DOI: http://dx.doi.org/10.30998/formatif.v9i1.2646

Oppong, S.H. (2013). The problem of sampling in qualitative research. Asian Journal of Management Sciences and Education, 2 (2), 202-210.

Pabuccu, A. (2008). Improving 11th Grade Students' Understanding of Acid-Base Concepts by Using 5e Learning Cycle Model. Unpublished doctoral dissertation. Ankara: Middle East Technical University.

Purtadi, S., dan Sari, L.P. 2011. Analisis Miskonsepsi Konsep Laju dan Kesetimbangan Kimia pada Siswa SMA. Makalah. Yogyakarta: Universitas Negeri Yogyakarta.

Sanger, M.J., \& Greenbowe, T.J. (1997). Common student misconception in electrochemistry: galvanic, electrolytic, and concentration cells. Journal of Research in Science Teaching (JRST), 34 (4), 377-398. https://doi.org/10.1002/(SICI)10982736(199704)34:4<377::AIDTEA7>3.0.CO;2-O

Sesen, B.A. \& Tarhan, L. (2011). Active-learning versus teacher-centered instruction for learning acid and base. Research in Science \& Technological Education, 29 (2), 205-226. https://doi.org/10.1080/02635143.2011.581630

Slavin, R.E.(2011). Psikologi Pendidikan Teori dan Praktik. Jakarta: PT. Indeks.

Sudjana, N. (2005). Dasar-Dasar Proses Belajar Mengajar. Bandung: Sinar Baru Algensindo.

Suparno, P. (2012). Miskonsepsi dan Perubahan Konsep dalam Pendidikan Fisika. Jakarta: Gramedia.

Treagust, D. F. (2006). Diagnostic Assessment in science as a means to improving teaching, learning, and retention. Proceedings of UniServe Science, Symposium: Assessment in Science Teaching and Learning. Uniserve Science: Sydney, Australia. Retrieved fromhttp://science.uniserve.edu.au/pubs/procs/2006/treagu st.pdf.

Tsui, C.Y., \& Treagust, D. (2010). Evaluating secondary students' scientific reasoning in genetics using a two-tier diagnostic instrument. International Journal of Science Education, 32(8), 1073-1098.

Winny, L., Taufik R., \& Ramalis. (2008). Identifikasi Miskonsepsi Materi IPBA di SMA dengan Menggunakan CRI (Certainty of Response Index) dalam Upaya Perbaikan Urutan Pemberian Materi IPBA Pada KTSP. Prosiding Seminar Nasional Penelitian, Pendidikan, dan Penerapan MIPA. Yogyakarta:Fakultas MIPA, Universitas Negeri Yogyakarta. 